\title{
Oncolytic Virus-Induced Autophagy in Glioblastoma
}

\author{
Margarita Kamynina ${ }^{1}$, Salome Tskhovrebova ${ }^{1}$, Jawad Fares ${ }^{2} \mathbb{D}$, Peter Timashev ${ }^{3,4,5} \mathbb{D}$, Anastasia Laevskaya ${ }^{1}$ \\ and Ilya Ulasov $1, *$ (D)
}

1 Group of Experimental Biotherapy and Diagnostic, Institute for Regenerative Medicine, Sechenov First Moscow State Medical University, 119991 Moscow, Russia; margaret.kamynina@gmail.com (M.K.); sali.bibikc@gmail.com (S.T.); ayaksveal@yandex.ru (A.L.)

2 Department of Neurological Surgery, Feinberg School of Medicine, Northwestern University, Chicago, IL 60611, USA; jawad.fares@northwestern.edu

3 Institute for Regenerative Medicine, Sechenov First Moscow State Medical University, 119991 Moscow, Russia; timashev_p_s@staff.sechenov.ru

4 Department of Polymers and Composites, N. N. Semenov Institute of Chemical Physics, 119991 Moscow, Russia

5 Chemistry Department, Lomonosov Moscow State University, 119991 Moscow, Russia

* Correspondence: ulasov.iv@1msmu.ru

Citation: Kamynina, M.;

Tskhovrebova, S.; Fares, J.; Timashev,

P.; Laevskaya, A.; Ulasov, I. Oncolytic

Virus-Induced Autophagy in

Glioblastoma. Cancers 2021, 13, 3482.

https: / / doi.org/10.3390/

cancers 13143482

Academic Editor: Vanessa

Soto-Cerrato

Received: 4 June 2021

Accepted: 7 July 2021

Published: 12 July 2021

Publisher's Note: MDPI stays neutral with regard to jurisdictional claims in published maps and institutional affiliations.

Copyright: (c) 2021 by the authors. Licensee MDPI, Basel, Switzerland. This article is an open access article distributed under the terms and conditions of the Creative Commons Attribution (CC BY) license (https:// creativecommons.org/licenses/by/ $4.0 /)$.
Simple Summary: Glioblastoma (GBM) is the most common and aggressive brain tumor with an incidence rate of nearly 3.19/100,000. Current therapeutic options fall short in improving the survival of patients with GBM. Various genetic and microenvironmental factors contribute to GBM progression and resistance to therapy. The development of gene therapies using self-replicating oncolytic viruses can advance GBM treatment. Due to GBM heterogeneity, oncolytic viruses have been genetically modified to improve the antiglioma effect in vitro and in vivo. Oncolytic viruses can activate autophagy signaling in GBM upon tumoral infection. Autophagy can be cytoprotective, whereby the GBM cells catabolize damaged organelles to accommodate to virus-induced stress, or cytotoxic, whereby it leads to the destruction of GBM cells. Understanding the molecular mechanisms that control oncolytic virus-induced autophagic signaling in GBM can fuel further development of novel and more effective genetic vectors.

Abstract: Autophagy is a catabolic process that allows cells to scavenge damaged organelles and produces energy to maintain cellular homeostasis. It is also an effective defense method for cells, which allows them to identify an internalized pathogen and destroy it through the fusion of the autophagosome and lysosomes. Recent reports have demonstrated that various chemotherapeutic agents and viral gene therapeutic vehicles provide therapeutic advantages for patients with glioblastoma as monotherapy or in combination with standards of care. Despite nonstop efforts to develop effective antiglioma therapeutics, tumor-induced autophagy in some studies manifests tumor resistance and glioma progression. Here, we explore the functional link between autophagy regulation mediated by oncolytic viruses and discuss how intracellular interactions control autophagic signaling in glioblastoma. Autophagy induced by oncolytic viruses plays a dual role in cell death and survival. On the one hand, autophagy stimulation has mostly led to an increase in cytotoxicity mediated by the oncolytic virus, but, on the other hand, autophagy is also activated as a cell defense mechanism against intracellular pathogens and modulates antiviral activity through the induction of ER stress and unfolded protein response (UPR) signaling. Despite the fact that the moment of switch between autophagic prosurvival and prodeath modes remains to be known, in the context of oncolytic virotherapy, cytotoxic autophagy is a crucial mechanism of cancer cell death.

Keywords: autophagy; oncolytic virus; apoptosis 


\section{Introduction}

Glioblastoma (GBM) is the most common lethal primary brain tumor among adults. Survival outcomes continue to be dismal despite aggressive therapeutic regimens that include surgical resection, chemotherapy, and radiation [1]. The median survival of patients does not exceed 20 months [2]. Therefore, the search for or development of effective antiglioma strategies is necessary to achieve a breakthrough in the current status quo. Most recently, anticancer therapy with oncolytic viruses showed a strong antiglioma effect [3] and became a viable option in clinics [4].

Oncolytic viruses are a vast group of agents that utilize the replication cycle of a host to deliver and express toxic viral proteins upon infection of various cancer cells [3]. Depending on the viral antigen structure and the virion's platform, oncolytic viruses may cause a characteristic inflammatory response [5,6], act as an adjuvant therapeutic $[7,8]$, serve as a vaccine agent in situ [9,10], function as an anticancer agent for systemic injection [11,12], and/or cause DNA damage in cancer cells [13]. Furthermore, oncolytic viruses can lead to multiple types of programmed cell death [6,14-16] since targeted genes are involved in the cell signaling of apoptosis, pyroptosis, necroptosis, and autophagy.

Autophagy is a process that is characterized by the development of a double-membraned phagosome in response to cellular stress [17]. Autophagy is known to play a dual role in cell survival, both cytoprotective and cytotoxic. Under normal physiological conditions, autophagy is required to get rid of damaged organelles and mitochondria and to provide roadblocks for protein synthesis and energy storage [18]. During cancer progression, autophagy is used by the tumor to maintain the pathological state of the tumor cells [19]. In the context of cytotoxicity, the autophagic type of cell death resembles the process of cellular self-consumption due to stress the cell is unable to cope with. Autophagy induction is important for enhancing the cytotoxic effect mediated by the Newcastle disease virus [20] and other oncolytic viruses that are interferon- $\beta$-armed [16] or based on Delta24RGD [21]. Various oncolytic viruses have been studied in clinical and preclinical studies. Adenovirus, blueberry virus, herpes virus, parvovirus, picornavirus, and reovirus were investigated in human and veterenary medicine [22]. On clinicaltrials.gov (accessed on 20 April 2021), 20 trials have explored oncolytic viruses for GBM treatment. The most studied were Vaccinia virus, adenovirus, Newcastle Disease, and HSV.

Concerning the molecular basis, the main molecular regulators of autophagy in cancer are the LKB1-AMPK pathway, the PI3K/AKT pathway (via mTOR), Beclin 1, and p53 [23]. The autophagy regulation pathways in response to stress signals are shown in Figure 1. The cellular response to stress induced by an oncolytic virus-for example, CRAd-S-pK7involves the initiation and maintenance of intracellular signals using reactive oxygen species (ROS) [24], lipid products [25], and/or other signal transmitters. The modulation of these factors impacts the initiation of cellular signaling that is necessary for cell death and thus provides a challenge for anticancer approaches. Here, in this review, we explore the cellular and molecular events involved in the induction of cytoprotective autophagymediated responses to oncolytic viruses in glioblastoma, which reduces oncolytic efficacy, and mechanisms of cytoprotective-cytotoxic autophagy switch, which is possibly capable of improving the oncolytic effect. 


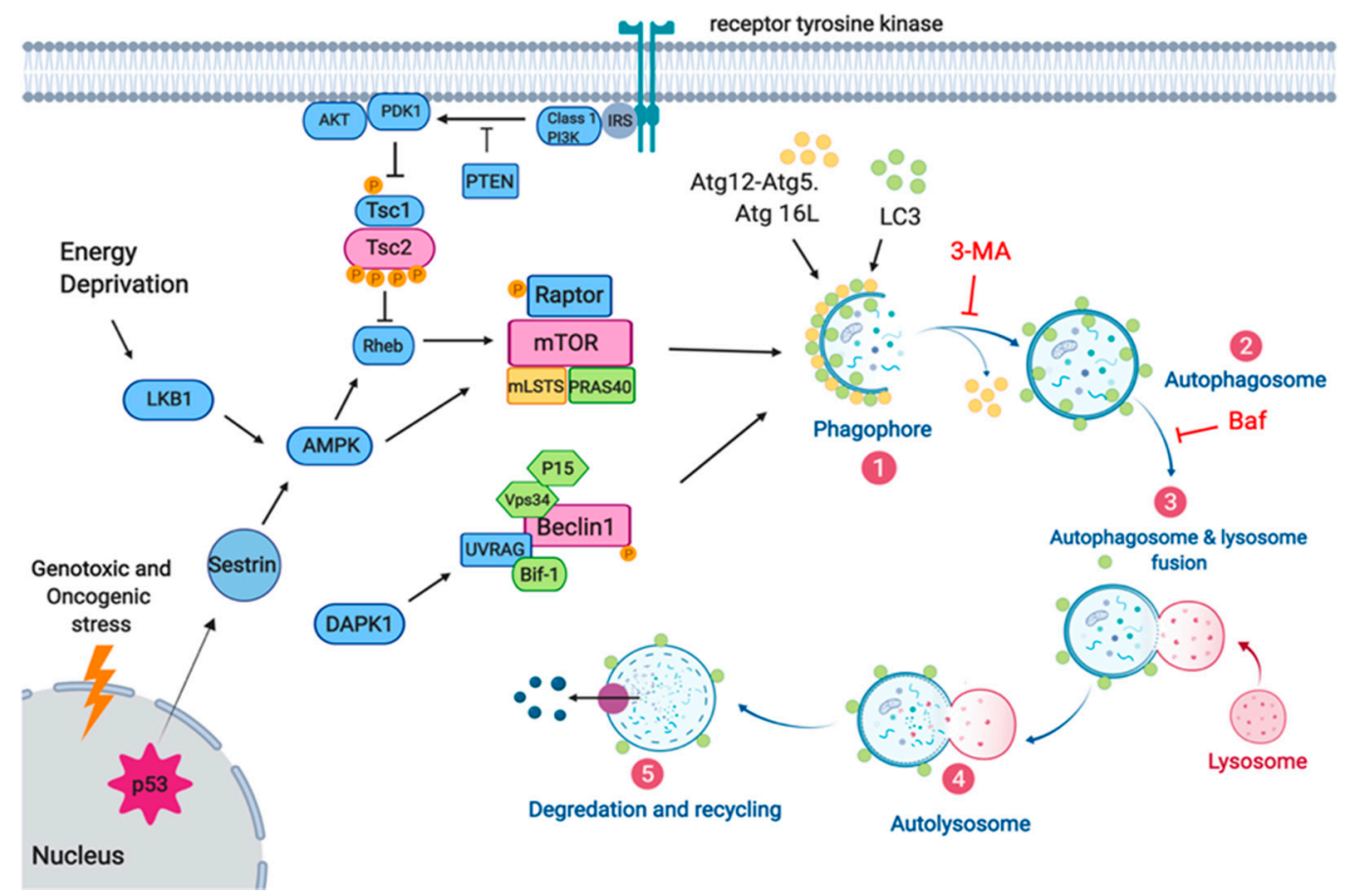

Figure 1. Autophagy regulation pathways in response to stress signal. The figure shows the pathway for the initiation of autophagy through the activation of a receptor tyrosine kinase. The autophagy process includes initiation, elongation, autophagosome formation, lysosome fusion, and degradation. The initiator complex is a base for launching the assembly of the autophagosomal membrane de novo. It consists of Beclin-1, Bcl-2, VPS (vacuolar protein sorting) kinase-34, and Atg14L proteins. The Atg5-Atg12 complex interacts with Atg16L1 and then participates in the elongation of the autophagosomal membrane. Atg4B cleaves LC3I to LC3II, which, after conjugation with PE (phosphatidylethanolamine), turns into an autophagosomal membrane-bound protein directly involved in membrane formation. After fusion, all membrane proteins (except LC3II) involved in this process leave the autophagosome.

\section{Autophagy in Cancer Cells as Both a Defense Mechanism Against Viruses and the Initiating Cell Death Process}

Autophagy signaling is vital to fight pathogens such as bacteria or viruses, but in transformed cells, autophagy signaling is weakened due to the inherent immunosuppressive properties of cancer cells [26,27]. As such, the response of tumor cells to viral infection by OVs is often diminished, despite partial responses witnessed against viral antigens. The differences in cellular responses triggered cancer biologists to explore the mechanisms of action that govern the OV-induced response.

Recent investigations indicate that the integral role of autophagy signaling in cancer cells is associated with stress resistance, hinting at the biological significance of autophagy in cell survival [28]. Therefore, autophagy helps cancer cells maintain cellular integrity after viral infection and permits cancer cells to strike a balance between the need to react to stressful stimuli and cell survival and protection. This established a paradigm whereby viral agents and antigens can be distinguished based on the cellular response and stress magnitude induced in cancer cells. In other words, released stress factors require autophagic induction as a response to the internalized viral agents in the cytoplasm to promote cancer cell adaptation and survival [29].

As already stated, oncolytic viruses induce autophagy, which results in cancer cell lysis; hence, OV agents may switch the cytoprotective role of autophagy to cytotoxic. Oncolytic viruses are considered a therapeutic option in neuro-oncology in general and glioblastoma in particular, whereby OVs are required to internalize into target cells and induce cellular death, affecting overall tumor proliferation. In the following sections, we highlight the cellular reactions mediated by oncolytic viruses. 


\section{Regulation of Apoptotic Proteins Provides Advantages for Oncolytic Virus-Mediated Cell Death}

Apoptosis is a key cellular mechanism that protects cells against viral infections [30]. Together with selective autophagy, apoptosis is an element of the protective immunity of the cell that eliminates microbes and enhances immune recognition of antigens expressed on cell surfaces. Similarly, endoplasmic reticulum stress (ER stress), which is followed by the unfolded protein response (UPR); apoptosis; and autophagy are signaling elements of neuroprotective protein unfolding during viral infection of the central neural system (CNS) [29].

Apoptosis as a prosurvival and/or prodeath process has been explored in glioblastoma cells treated with chemotherapeutic drugs or oncolytic viruses. Moreover, accumulating evidence $[31,32]$ suggests some correlation between glioblastoma resistance and the activity of apoptotic proteins. To date, the apoptotic pathways through which oncolytic viruses, such as M011L-oncolytic myxoma virus, CRAd-S-5/3, and Delta24RGD, kill glioma cells are not fully understood, and present data suggest a complex contribution of Bcl-2-like protein 4 (BAX) [33], p53 upregulated modulator of apoptosis protein (PUMA) [13], and B-cell lymphoma 2 protein (BCL2) $[21,33]$ in tumor inhibition. Most recently, it was shown that the inhibition of Bcl2 potentiates cancer cells to the M1 vector via upregulation of BCL2 antagonist/Killer 1 (Bak) [25]. Previously, it was reported that primary GBM samples are upregulated with survivin (Birc5) [34] and BCL2 [35], preventing the induction of BAX, $\mathrm{BID}$, or BAK upon oncolytic virus infection through the expression of inhibitory molecules for apoptosis. Therefore, apoptosis induction during oncolytic virus infection results in BAX-independent cell death by promoting durable cellular stress. Thus, revealing the mechanism of regulation of apoptotic proteins will allow better stimulation of OV-mediated cell death.

\section{The Link between Apoptosis and Autophagy: ER Stress}

The prolonged stress response via the expression of proapoptotic proteins may result in a disturbance in the endoplasmic reticulum (ER) environment as unprocessed proteins accumulate in the ER. This disproportion with the expression of antiapoptotic proteins such as BCL2 and BCLXL governs cellular reactions and causes durable stress [36]. In cells such as glioma ER stress recruits elements of the tumor microenvironment [37] to enhance tumor progression and expansion via ER signaling. This includes inositol-requiring enzyme $1 \alpha$ (IRE1 $\alpha$ ), activating transcription factor 6 (ATF6), and pancreatic ER kinase-like ER kinase (PERK) localized in the ER. Additionally, IRE1 $\alpha$ acts as ER stress sensor [38]. Interestingly, both PERK and ATF1 are inducers of autophagy, while IRE1 $\alpha$ is its negative regulator. Moreover, the lower the level of IRE1 $\alpha$ expression in glioblastoma cells, the higher the therapeutic effectiveness of the oncolytic virus M1 [39]. Emerging evidence suggests that X-box binding protein (XBP1), an IRE1 $\alpha$ downsignaling, and calreticulin, an ER-resident chaperone that has been localized to the surface of tumor cells [40], are both linked to glioma progression [38]. Tumors exhibiting high IRE1 $\alpha$ activity also correlated with bad outcomes and shorter median survival in patients. Therefore, the accumulation of unprocessed proteins in the ER due to apoptotic protein expression produces ER stress. ER stress in turn promotes tumor progression. However, at the same time, ER stress is linked to autophagy activation, and a low level of IRE1 alpha, a negative regulator of autophagy, contributes to the higher effectiveness of antiglioma agents. Thus, ER stress plays a dual role in tumor progression. It recruits elements of the tumor microenvironment to enhance tumor progression but also improves the therapeutic efficacy of the oncolytic virus M1 through inducing autophagy [39].

\section{Unfolded Protein Response (UPR): One Process, Two Impacts}

The unfolded protein response is a process activated due to overwhelming ER stress and the inability of tumor cells to counteract it. It remains unknown at which point the UPR leads to cell death, how it promotes cellular apoptosis, and/or when it promotes 
cell survival [41]. UPR has long been viewed as an adaptive program to sustain cellular homeostasis to counterbalance ER stress. ER stress is often developed as a secondary mechanism to drug treatment or viral persistence. This is the case with HCMV [42], the hepatitis C virus [43], and the hepatitis B virus [44]. The infection of normal brain cells $[45,46]$ and/or glioma cells $[47,48]$ with retroviruses, NDV, or MDA-7/IL-24 also leads to ER modifications in cellular programming. Treatment regimens and viral proteins may put the ER under stress, but vulnerable cells cope with stress-induced stimuli. However, if failure in eliminating the source of cellular stress occurs and extensive ER stress is unable to restore ER balance, the activated UPR aims to eliminate the damaged cells and promote cell death. Therefore, UPR-modulating drugs and approaches have emerged as promising candidates for mono- and combination therapy with temozolomide against glioblastoma.

When UPR fails to rebuild tumor homeostasis, autophagy induction occurs. Autophagy is a compensatory mechanism to eliminate the burden of toxic proteins in the ER. Damaged organelles can be subjected to destruction inside autophagosomes. Interestingly, a study completed by Mahoney et al. [49] described the mechanism of UPR inhibition caused by an oncolytic rhabdovirus that improved its cytotoxicity against adherent and primary patient-derived glioblastoma cells. Growing evidence suggests that the fitness and fate of tumor cells infected with oncolytic viruses can be the result of countermovement between UPR and autophagy. Li et al. were the first to demonstrate a link between autophagy induction and tumor resistance upon infection with an oncolytic virus [39]. In this study, autophagy was shown to follow UPR. In particular, infection with oncolytic M1-alphavirus in U87 glioma cells triggers UPR and subsequent autophagy, while blocking UPR and autophagy resulted in enhanced antitumor efficacy of the vector. Since then, various attempts have been made to explain the response mechanism that governs glioma protection against infection. It turned out that M1 activates UPR in primary malignant glioma cells via binding of an incorrectly folded protein to the ER chaperone Bip / GRP78. This is followed by the release of three membrane-bound proteins: IRE1, PERK, and ATF6. Currently, it is understood that UPR is regulated by membrane-incorporated sensors including double-stranded RNA-activated protein kinase (PKR)-like ER kinase (PERK), activating transcription factor 6 (ATF6), and inositol-requiring enzyme 1 (IRE1). Thus, in the context of molecular basis, while PERK and ATF6 are responsible for the induction of autophagy, IRE1 exhibits dualism in autophagy regulation. Additionally, activation of PERK-eIF2a-ATF4 affected the activity of Beclin 1, ATG16L1, and p62 [50], suggesting a link between UPR and autophagy modulation. Meanwhile, autophagy and thus UPR are shown to play a prosurvival role.

On the molecular level, the variability of the UPR has been studied by modulating the level of IRE1a expression in glioblastoma cells. Blocking IRE1a leads to the inhibition of the expanded protein response, which is sufficient for the virions' assembly and their release from the infected cells. At the same time, the increase in viral spread by stimulating the UPR is one of the approaches to promote tumor cell killing. Prasad et al. demonstrated that the UPR was greatly enhanced by the simultaneous treatment of tumor cells with adenovirus and the inhibitor of Golgi-specific brefeldin A-resistant guanine nucleotide exchange factor 1 (GBF1) [51]. Moreover, the boost of oncolytic virus titer and the increase in cytopathic effect were attributed to tumor cells, suggesting a dependence of HAdVC5 or HAdV-B on the UPR response. Considering all the above, since most anticancer studies use the HAdV-C5 as a vector to deliver a therapeutic payload to the target cells, stimulation of UPR, activation of autophagy, and progeny release become paramount tasks that affect oncolytic virus spreading. This rule can be applied to other oncolytic viruses such as mouse cytomegalovirus (MCMV) [50] and Kaposi-sarcoma-associated herpesvirus (KSHV) [52], which can infect and persist in neural cells. Another example of ER stress and autophagy activation is the infection of glioma cells with Chikungunya (CHIKV) alphavirus [53]. In vitro experiments showed that the oncolytic virus required autophagy induction for viral replication. A similar effect was seen with an adenovirus that uses Golgi and ER containers for virion release, suggesting a role for autophagy in antipathogen 
defense [54]. In this regard, we consider that compared to autophagy, apoptosis might be more devastating for glioma cells, since the lack of regenerative functions made neural stem cells vulnerable to destruction. Therefore, the UPR becomes an adaptive reaction of target cells to protect themselves from the accumulation of toxic proteins, including viral ones. In support of this hypothesis, during host cell infection, adenoviruses synthesize an excessive amount of hexon and fibers that are not used for new capsid assembly [55]. Additionally, it has been shown that Nef-protein, encoded by human immunodeficiency virus type 1 (HIV-1), blocks the fusion of the autophagosome with the lysosome, thereby keeping the virus inside cells [56]. Later, the virus found to encodes the protein Tat promote autophagy in neuronal cells [57] and gliomas via BAG3 signaling [57].

Overall, UPR plays a dual role in cancer cell survival. On the one hand, UPR is one of the pathways of autophagy induction and thus is capable of enhancing tumor resistance to infection with oncolytic vectors, but, on the other hand, stimulation of UPR promotes enhanced virions' assembly and release, thus promoting cytotoxicity. Since various OVs, such as reolysin [58], virus M1 [39], HAdV-C2-dE3B_GFP [59], 34.5ENVE [60], and hTertAd [61], modulate or require UPR to shift the balance between cell defense and cytotoxicity, establishing a link between cell defense and the viral response mechanism has broader clinical connotations.

\section{Cytotoxic Autophagy in Studies with Oncolytic Viruses}

As it was demonstrated previously, phenotypical and genotypical changes acquired after therapy produce aggressive subtypes of GBM cells that are resistant to the standard of therapy $[62,63]$. Therefore, much effort has been made to understand the mechanism of GBM resistance and discover novel molecular targets and potential effective drugs to target this disease [32,33].

Infection of GBM cells with an oncolytic virus causes the production and accumulation of viral proteins in the cytoplasm and the accumulation of unfolded proteins in the ER. These conditions launch transcription and translation of proteins to restore the cellular "status quo". While UPR aims to remove proteins from the ER and promote cell survival, the prolonged UPR also triggers autophagy via the induction of autophagy-related proteins [64].

It is worth mentioning that various adenoviruses, such as OBP301 [65], delta24RGD [66],

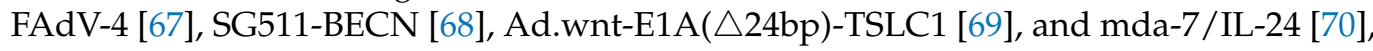
require autophagy to induce programmed cell death [71]. Among all vectors, conditionally replicating adenoviruses (CRAds) are promising agents for the treatment of tumors because of their ability to multiply and cause lysis of tumor cells and their surroundings [72]. Over the decades, it has been shown that protease L3 and E3-11.6-kDa adenovirus death protein cause the reorganization of host skeleton and contribute to adenovirus spreading [73,74]. To avoid side effects and improve tropism for the tumor, the virus is genetically engineered with the insertion of the human telomerase reverse transcriptase promoter (hTERT), which affects the expression of the adenoviral E1A gene, allowing oncolytic virus replication only in tumor cells (telomerase-positive cells) [75,76]. E1A induces caspase-3-mediated apoptosis independent of p53 [77]. A study by Ito et al. showed that cytotoxic autophagy is mediated by the blockade of the mTOR signaling pathway after exposure to hTERT-Ad viruses of U373-MG and U87-MG cells in vivo and in vitro [75]. Whether these events are important for autophagy regulation remains to be investigated, but the deletion of protease ICP10K [78], known for binding with Beclin 1, from the genome of HSV2, another vastly used gene therapy vehicle, triggers cell-specific apoptosis [79] in cancer cells. The precise mechanism of viral proteins' influence (CRAds and HSV-1) on autophagy is depicted in Figure 2. 


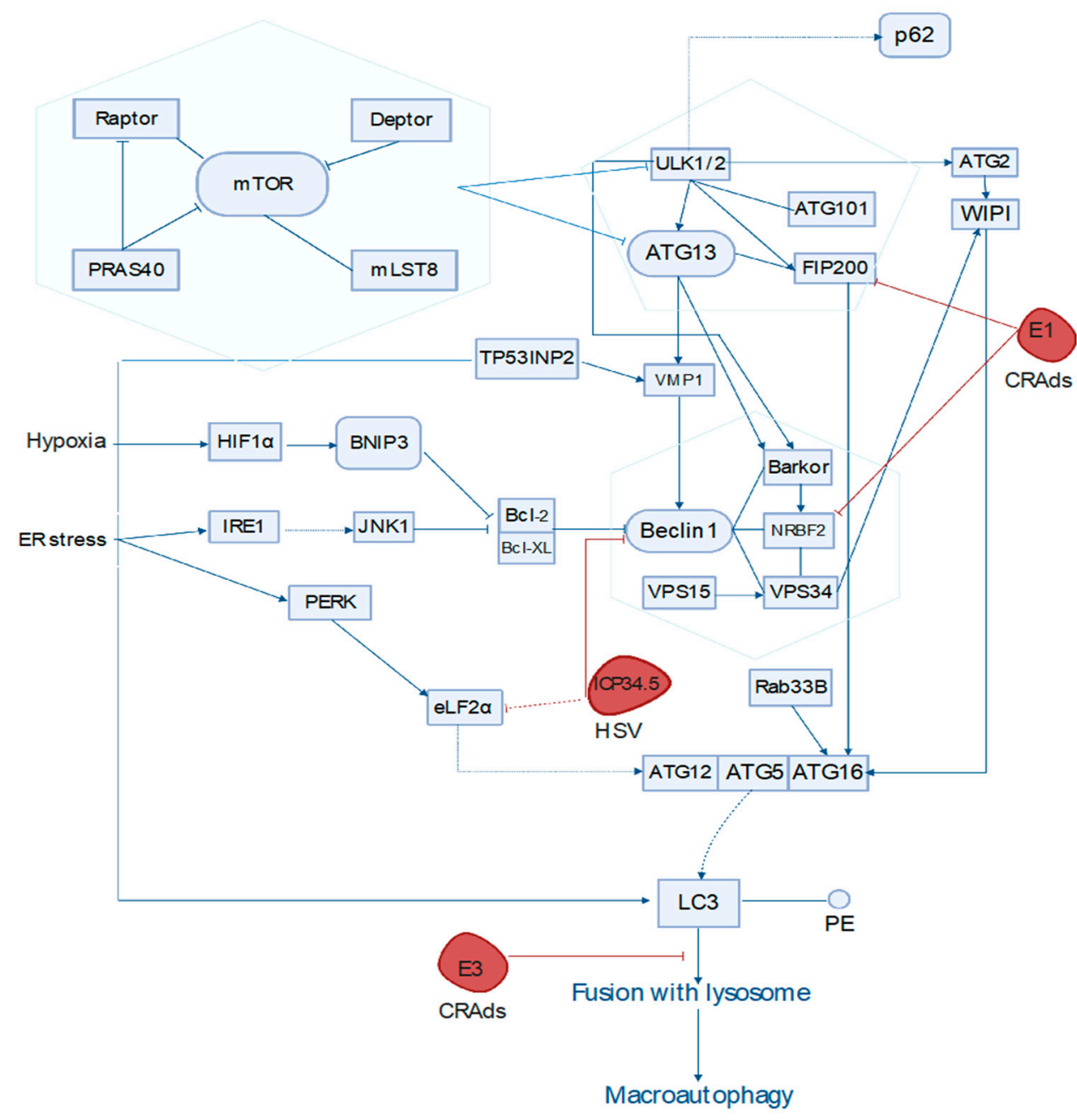

Figure 2. Influence of viral proteins (CRAds and HSV-1) on autophagy. Intermittent lines describe the indirect effect, and continuous lines describe the direct. Adenoviral E1 protein inhibits FIP200 and NRBF2 proteins in the autophagy pathway. Interaction of FIP200 and ATG16 defies ULK1-dependent or independent induction of autophagy. E3 protein prevents the fusion of lysosomes. ICP34.5 of HSV-1 inhibits autophagy, inhibiting eLF2 $\alpha$ and Beclin1.

In the context of other oncolytic vectors and autophagy activation, the herpes virus also contains the ICP34.5 protein significant for oncolytic virotherapy, which is responsible for binding to Beclin 1 at the subsequent inhibition of eIF2 $\alpha$. Additionally, Kanai et al. showed that the $\Delta 68 \mathrm{H}-6$ virus modified HSV-1 (with deletion $\gamma 34.5$ ) is an effective vector for the treatment of glioblastoma since it is not able to inhibit autophagy [80]. Another example is flavivirus Zika that also restricts ER stress turnover for virus replication by cleavage of the FAM134B, an autophagy receptor that is responsible for targeted ER degradation [81]. Inhibition of intracellular ATP levels and IRE1 $\alpha$ or PERK causes cytotoxic autophagy mediated by Newcastle disease virus (NDV) [82] and M1 [39] viruses, relatively. Thus, various oncolytic viruses are capable of inducing cytotoxic autophagy which promotes their oncolytic efficacy.

Despite the general consesnus reached on the role of autophagy in oncolytic virus cytotoxicity, several studies reported a negative contribution of autophagy in CRAdmediated cell death, suggesting the cytoprotective role of autophagy during virus infection. For instance, a study by Botta et al. [83] showed that d1922-947 triggered an autophagy response, whereas the inhibition of infected cells with 3-Ma increased the anticancer effect mediated by the viral vector. Bhutia et al. [83] further observed cytoprotective autophagy in the case of prostate cancer cell infection with Ad.mda-7 virus [84]. Although both viral 
groups used delta 24 adenovirus backbone, infected cells displayed different autophagic responses.

\section{Modulation of Cytotoxic Autophagy with Oncolytic Virus or Drug Combination}

Overall, this review highlights how important it is to counteract autophagy mediated by infected cells. Despite clear evidence that OV modulates autophagy, the exact method of induction of cytotoxic autophagy and the cellular proteins involved remain unclear. Recent findings indicate that ATG proteome provides a cellular function outside autophagy signaling, which involves a host-pathogen interaction [85]. More than 20 ATG-based proteins have been shown to inhibit or support viral replication of several self-replicated vectors, such as adenoviruses (d1922-947 [83], delta24RGD [66,86], CRAd-S-pK7 [87]), adchikungunya virus [88], HSV( $\triangle 68 \mathrm{H}-6$ and 1716-6 [80]), or NDV (strain Beaudette C [20]). It appears that various vectors have preferences for autophagy protein expression and that such interaction suggests an interplay between autophagy-related proteins and viral replication cycles. This evidence may confirm previous findings that siRNA interference against ATG5 or Beclin1 suppresses oncolytic vector replication and progeny release in the case of NDV (strain Beaudette C [20]) or adenovirus-based CRAd-S-pK7 [87] and Adhz60 (deltaE1B) [89]. In addition, an association between herpes simplex virus-1 produced proteins [90,91] or enterovirus A71 [92] and autophagy-related proteins has recently been reported, further confirming the possibility of the nonautophagy canonical function of autophagy-related proteins during the replication of several oncolytic viruses. Thus, different oncolytic viruses are capable of inducing various forms of autophagy, including both cytotoxic and cytoprotective forms.

\section{Conclusions}

Cell death is a highly conserved process, the understanding of which is essential for the construction of experimental drugs, such as oncolytic viruses that have shown promising results in glioblastoma treatment. The effectiveness of therapy depends on the ability of the oncolytic virus to infect and spread in tumor cells. One of the main problems in the introduction of oncolytic virotherapy in clinics is an incomplete understanding of the mechanisms of action of the oncolytic virus on the tumor and its microenvironment. More specifically, this includes autophagy, which induces cell death and enhances virus particle spread through the modulation of UPR.

Cell death via oncolytic virus infection involves the recognition of viral particles by host cells followed by an attempt to destroy them via autophagy inside the autophagosomes. Accordingly, ER stress and UPR are modulators of the vesicular stomatitis virus [49] and herpes simplex virus [60] cytotoxicity during cellular response to infection. Moreover, proapoptotic protein expression seems to play an important role in this process. Despite a large number of studies in the field of autophagy and oncolytic viruses, it is still unclear what precedes the prosurvival to prodeath autophagy switch. In addition, it became known that the form of autophagy depends on the type of oncolytic vector. Therefore, it is important to understand the pathways that regulate autophagy signaling and determine ways to enhance the cytopathic effect mediated by oncolytic vectors [93].

\section{Future Directions}

Currently, the therapeutic effect of oncolytic viruses is achieved by combining different types of therapies: for example, oncolytic virotherapy and chemotherapy. It has recently been acknowledged that the activation of cellular autophagy can be greatly enhanced by the addition of autophagy-inducing drugs such as rapamycin [94,95]. It is known that rapamycin is an immunosuppressor that acts through the interaction between the $12-\mathrm{kDa}$ FK506-binding protein (FKBP12), a rapamycin-associated cellular protein, and FKBP12 target 1 (FRAP/mTOR/RAFT1). It inhibits G cell cycle progression in mammalian cells [96]. Given the fact that various oncolytic viruses arrest cells in the $S$ phase of the cell cycle, an additive effect between oncolytic viruses—for example, Myxoma virus [97,98], Newcastle 
virus [20], adenovirus OBP-405 [71], vaccinia virus JX-594 [99] and vvDD-EGFP [100], IFN-sensitive VSV-mutant strain (VSV(DeltaM51) [101], and rapamycin-may result in increased cytotoxicity. Strong additive effects can also be seen by the combination of oncolytic herpes simplex viruses and cell death inducers of apoptosis (etoposide) [102], the combinaiton of ionizing radiation with parvovirus M1 or myxoma virus [103-105], and the combination of inducers of cell cycle arrest and apoptosis with oncolytic viruses, such as Newcastle virus, vericular stomatitis virus, or vaccinia virus in temozolomidetreated glioblastoma cells $[106,107]$. Thus, a combination of oncolytic virotherapy with autophagy-stimulating agents seems to be a promising strategy for future clinical trials.

Author Contributions: Conceptualization, I.U., M.K. and S.T.; methodology, M.K. and S.T.; data curation, M.K. and S.T.; writing—original draft preparation, M.K., S.T., J.F., I.U. and A.L.; writingreview and editing, M.K., P.T., I.U., J.F., S.T. and A.L.; visualization, M.K., S.T. and A.L.; supervision, I.U.; project administration, I.U.; funding acquisition, I.U. and P.T. All authors have read and agreed to the published version of the manuscript.

Funding: This research was funded by the Ministry of Science and Higher Education of the Russian Federation within the framework of state support for the creation and development of World-Class Research Centers, “Digital biodesign and personalized healthcare” №: 075-15-2020-926.

Conflicts of Interest: The authors declare no conflict of interest.

\section{Abbreviations}

\begin{tabular}{|c|c|}
\hline ATF6 & activating transcription factor 6 \\
\hline ATG5 and ATG7 & autophagy-related protein 5 and 7 \\
\hline BAK & BCL2 Antagonist/Killer 1 \\
\hline BAX & bcl-2-like protein 4 \\
\hline BID & pro-apoptotic Bcl-2 protein \\
\hline BCL2 & B-cell lymphoma 2 protein \\
\hline BCLXL & B-cell lymphoma-extra-large \\
\hline CMV & cytomegalovirus \\
\hline CNS & central neural system \\
\hline FKBP12 & 12-kDa FK506-binding protein \\
\hline GBM & glioblastoma \\
\hline $\operatorname{IRE} 1 \alpha$ & inositol-requiring enzyme $1 \alpha$ \\
\hline JNK & c-Jun N-Terminal Kinase \\
\hline ER & endoplasmic reticulum \\
\hline HadV-C5 & human adenovirus, $\mathrm{C}$ type, strain 5 \\
\hline HDACi & histone deacetylase inhibitors \\
\hline HIV-1 & human immunodeficiency virus, type 1 \\
\hline HSV & herpes simplex virus \\
\hline OV & oncolytic virus \\
\hline PE & phosphatidylethanolamine \\
\hline PERK & pancreatic ER kinase-like ER kinase \\
\hline ROS & reactive oxygen species \\
\hline UPR & unfolded protein response \\
\hline VACV & vaccinia virus \\
\hline VPS & vacuolar protein sorting \\
\hline XBP1 & X-box binding protein \\
\hline
\end{tabular}

\section{References}

1. Stupp, R.; Mason, W.P.; van den Bent, M.J.; Weller, M.; Fisher, B.; Taphoorn, M.J.; Belanger, K.; Brandes, A.A.; Marosi, C.; Bogdahn, U.; et al. European Organisation for, T. Treatment of Cancer Brain, G. Radiotherapy, G. National Cancer Institute of Canada Clinical Trials, Radiotherapy plus concomitant and adjuvant temozolomide for glioblastoma. N. Engl. J. Med. 2005, 352, 987-996. [CrossRef] 
2. Giordano, F.A.; Brehmer, S.; Murle, B.; Welzel, G.; Sperk, E.; Keller, A.; Abo-Madyan, Y.; Scherzinger, E.; Clausen, S.; Schneider, F.; et al. Intraoperative Radiotherapy in Newly Diagnosed Glioblastoma (INTRAGO): An Open-Label, Dose-Escalation Phase I/II Trial. Neurosurgery 2019, 84, 41-49. [CrossRef]

3. Aurelian, L. Oncolytic viruses as immunotherapy: Progress and remaining challenges. OncoTargets Ther. 2016, 9, 2627-2637. [CrossRef]

4. Lang, F.F.; Conrad, C.; Gomez-Manzano, C.; Yung, W.K.A.; Sawaya, R.; Weinberg, J.S.; Prabhu, S.S.; Rao, G.; Fuller, G.N.; Aldape, K.D.; et al. Phase I Study of DNX-2401 (Delta-24-RGD) Oncolytic Adenovirus: Replication and Immunotherapeutic Effects in Recurrent Malignant Glioma. J. Clin. Oncol. 2018, 36, 1419-1427. [CrossRef]

5. Umer, B.A.; Noyce, R.S.; Franczak, B.C.; Shenouda, M.M.; Kelly, R.G.; Favis, N.A.; Desaulniers, M.; Baldwin, T.A.; Hitt, M.M.; Evans, D.H. Deciphering the Immunomodulatory Capacity of Oncolytic Vaccinia Virus to Enhance the Immune Response to Breast Cancer. Cancer Immunol. Res. 2020, 8, 618-631. [CrossRef]

6. Pelin, A.; Foloppe, J.; Petryk, J.; Singaravelu, R.; Hussein, M.; Gossart, F.; Jennings, V.A.; Stubbert, L.J.; Foster, M.; Storbeck, C.; et al. Deletion of Apoptosis Inhibitor F1L in Vaccinia Virus Increases Safety and Oncolysis for Cancer Therapy. Mol. Ther. Oncolytics 2019, 14, 246-252. [CrossRef]

7. Grekova, S.P.; Rommelaere, J.; Raykov, Z. Parvoviruses-tools to fine-tune anticancer immune responses. Oncoimmunology 2012, 1, 1417-1419. [CrossRef] [PubMed]

8. Berghauser Pont, L.M.; Balvers, R.K.; Kloezeman, J.J.; Nowicki, M.O.; van den Bossche, W.; Kremer, A.; Wakimoto, H.; van den Hoogen, B.G.; Leenstra, S.; Dirven, C.M.; et al. In vitro screening of clinical drugs identifies sensitizers of oncolytic viral therapy in glioblastoma stem-like cells. Gene. Ther. 2015, 22, 947-959. [CrossRef]

9. Merlino, G.; Herlyn, M.; Fisher, D.E.; Bastian, B.C.; Flaherty, K.T.; Davies, M.A.; Wargo, J.A.; Curiel-Lewandrowski, C.; Weber, M.J.; Leachman, S.A.; et al. The state of melanoma: Challenges and opportunities. Pigment. Cell Melanoma Res. 2016, $29,404-416$. [CrossRef]

10. Liu, B.L.; Robinson, M.; Han, Z.Q.; Branston, R.H.; English, C.; Reay, P.; McGrath, Y.; Thomas, S.K.; Thornton, M.; Bullock, P.; et al. ICP34.5 deleted herpes simplex virus with enhanced oncolytic, immune stimulating, and anti-tumour properties. Gene. Ther. 2003, 10, 292-303. [CrossRef]

11. Huang, L.L.; Li, X.; Zhang, J.; Zhao, Q.R.; Zhang, M.J.; Liu, A.A.; Pang, D.W.; Xie, H.Y. MnCaCs-Biomineralized Oncolytic Virus for Bimodal Imaging-Guided and Synergistically Enhanced Anticancer Therapy. Nano Lett. 2019, 19, 8002-8009. [CrossRef] [PubMed]

12. Hirvinen, M.; Rajecki, M.; Kapanen, M.; Parviainen, S.; Rouvinen-Lagerstrom, N.; Diaconu, I.; Nokisalmi, P.; Tenhunen, M.; Hemminki, A.; Cerullo, V. Immunological effects of a tumor necrosis factor alpha-armed oncolytic adenovirus. Hum. Gene. Ther. 2015, 26, 134-144. [CrossRef] [PubMed]

13. Kaverina, N.V.; Kadagidze, Z.G.; Borovjagin, A.V.; Karseladze, A.I.; Kim, C.K.; Lesniak, M.S.; Miska, J.; Zhang, P.; Baryshnikova, M.A.; Xiao, T.; et al. Tamoxifen overrides autophagy inhibition in Beclin-1-deficient glioma cells and their resistance to adenovirusmediated oncolysis via upregulation of PUMA and BAX. Oncogene 2018, 37, 6069-6082. [CrossRef]

14. Ali-Saeed, R.; Alabsi, A.M.; Ideris, A.; Omar, A.R.; Yusoff, K.; Ali, A.M. Evaluation of Ultra-Microscopic Changes and Proliferation of Apoptotic Glioblastoma Multiforme Cells Induced by Velogenic Strain of Newcastle Disease Virus AF2240. Asian Pac. J. Cancer Prev. 2019, 20, 757-765. [CrossRef]

15. Jaime-Ramirez, A.C.; Dmitrieva, N.; Yoo, J.Y.; Banasavadi-Siddegowda, Y.; Zhang, J.; Relation, T.; Bolyard, C.; Wojton, J.; Kaur, B. Humanized chondroitinase ABC sensitizes glioblastoma cells to temozolomide. J. Gene. Med. 2017, 19, e2942. [CrossRef]

16. Huang, H.; Xiao, T.; He, L.; Ji, H.; Liu, X.Y. Interferon-beta-armed oncolytic adenovirus induces both apoptosis and necroptosis in cancer cells. Acta Biochim. Biophys. Sin. (Shanghai) 2012, 44, 737-745. [CrossRef]

17. Tang, D.; Kang, R.; Berghe, T.V.; Vandenabeele, P.; Kroemer, G. The molecular machinery of regulated cell death. Cell Res. 2019, 29, 347-364. [CrossRef]

18. Madeo, F.; Zimmermann, A.; Maiuri, M.C.; Kroemer, G. Essential role for autophagy in life span extension. J. Clin. Investig. 2015, 125, 85-93. [CrossRef]

19. Ulasov, I.V.; Lenz, G.; Lesniak, M.S. Autophagy in glioma cells: An identity crisis with a clinical perspective. Cancer Lett. 2018, 428, 139-146. [CrossRef]

20. Meng, C.; Zhou, Z.; Jiang, K.; Yu, S.; Jia, L.; Wu, Y.; Liu, Y.; Meng, S.; Ding, C. Newcastle disease virus triggers autophagy in U251 glioma cells to enhance virus replication. Arch. Virol. 2012, 157, 1011-1018. [CrossRef]

21. Klein, S.R.; Piya, S.; Lu, Z.; Xia, Y.; Alonso, M.M.; White, E.J.; Wei, J.; Gomez-Manzano, C.; Jiang, H.; Fueyo, J. C-Jun N-terminal kinases are required for oncolytic adenovirus-mediated autophagy. Oncogene 2015, 34, 5295-5301. [CrossRef] [PubMed]

22. Beguin, J.; Nourtier, V.; Gantzer, M.; Cochin, S.; Foloppe, J.; Balloul, J.M.; Laloy, E.; Tierny, D.; Klonjkowski, B.; Quemeneur, E.; et al. Safety studies and viral shedding of intramuscular administration of oncolytic vaccinia virus TG6002 in healthy beagle dogs. BMC Vet. Res. 2020, 16, 307. [CrossRef] [PubMed]

23. Chen, N.; Debnath, J. Autophagy and tumorigenesis. FEBS Lett. 2010, 584, 1427-1435. [CrossRef]

24. Ulasov, I.V.; Sonabend, A.M.; Nandi, S.; Khramtsov, A.; Han, Y.; Lesniak, M.S. Combination of adenoviral virotherapy and temozolomide chemotherapy eradicates malignant glioma through autophagic and apoptotic cell death in vivo. Br. J. Cancer 2009, 100, 1154-1164. [CrossRef] [PubMed] 
25. Tan, Y.; Lin, Y.; Li, K.; Xiao, X.; Liang, J.; Cai, J.; Guo, L.; Li, C.; Zhu, W.; Xing, F.; et al. Selective Antagonism of Bcl-xL Potentiates M1 Oncolysis by Enhancing Mitochondrial Apoptosis. Hum. Gene. Ther. 2018, 29, 950-961. [CrossRef] [PubMed]

26. Ryskalin, L.; Gaglione, A.; Limanaqi, F.; Biagioni, F.; Familiari, P.; Frati, A.; Esposito, V.; Fornai, F. The Autophagy Status of Cancer Stem Cells in Gliobastoma Multiforme: From Cancer Promotion to Therapeutic Strategies. Int. J. Mol. Sci. $2019,20,3824$. [CrossRef]

27. Li, T.F.; Xu, Y.H.; Li, K.; Wang, C.; Liu, X.; Yue, Y.; Chen, Z.; Yuan, S.J.; Wen, Y.; Zhang, Q.; et al. Doxorubicin-polyglycerolnanodiamond composites stimulate glioblastoma cell immunogenicity through activation of autophagy. Acta Biomater. 2019, 86, 381-394. [CrossRef]

28. Degenhardt, K.; Mathew, R.; Beaudoin, B.; Bray, K.; Anderson, D.; Chen, G.; Mukherjee, C.; Shi, Y.; Gelinas, C.; Fan, Y.; et al. Autophagy promotes tumor cell survival and restricts necrosis, inflammation, and tumori8enesis. Cancer Cell 2006, 10, 51-64. [CrossRef] [PubMed]

29. Kroemer, G.; Marino, G.; Levine, B. Autophagy and the integrated stress response. Mol. Cell 2010, 40, 280-293. [CrossRef]

30. Roulston, A.; Marcellus, R.C.; Branton, P.E. Viruses and apoptosis. Annu. Rev. Microbiol. 1999, 53, 577-628. [CrossRef]

31. Gratas, C.; Sery, Q.; Rabe, M.; Oliver, L.; Vallette, F.M. Bak and Mcl-1 are essential for Temozolomide induced cell death in human glioma. Oncotarget 2014, 5, 2428-2435. [CrossRef] [PubMed]

32. Kouri, F.M.; Jensen, S.A.; Stegh, A.H. The role of Bcl-2 family proteins in therapy responses of malignant astrocytic gliomas: Bcl2L12 and beyond. Sci. World J. 2012, 2012, 838916. [CrossRef] [PubMed]

33. Pisklakova, A.; McKenzie, B.; Zemp, F.; Lun, X.; Kenchappa, R.S.; Etame, A.B.; Rahman, M.M.; Reilly, K.; Pilon-Thomas, S.; McFadden, G.; et al. M011L-deficient oncolytic myxoma virus induces apoptosis in brain tumor-initiating cells and enhances survival in a novel immunocompetent mouse model of glioblastoma. Neuro Oncol. 2016, 18, 1088-1098. [CrossRef] [PubMed]

34. Blahovcova, E.; Richterova, R.; Kolarovszki, B.; Dobrota, D.; Racay, P.; Hatok, J. Apoptosis-related gene expression in tumor tissue samples obtained from patients diagnosed with glioblastoma multiforme. Int. J. Mol. Med. 2015, 36, 1677-1684. [CrossRef] [PubMed]

35. Kleinschmidt-DeMasters, B.K.; Heinz, D.; McCarthy, P.J.; Bobak, J.B.; Lillehei, K.O.; Shroyer, A.L.; Shroyer, K.R. Survivin in glioblastomas. Protein and messenger RNA expression and comparison with telomerase levels. Arch. Pathol. Lab. Med. 2003, 127, 826-833. [CrossRef]

36. Yadav, R.K.; Chae, S.W.; Kim, H.R.; Chae, H.J. Endoplasmic reticulum stress and cancer. J. Cancer Prev. 2014, 19, 75-88. [CrossRef]

37. Martinon, F. Targeting endoplasmic reticulum signaling pathways in cancer. Acta Oncol. 2012, 51, 822-830. [CrossRef]

38. Lhomond, S.; Avril, T.; Dejeans, N.; Voutetakis, K.; Doultsinos, D.; McMahon, M.; Pineau, R.; Obacz, J.; Papadodima, O.; Jouan, F.; et al. Dual IRE1 RNase functions dictate glioblastoma development. EMBO Mol. Med. 2018, 10, e7929. [CrossRef]

39. Li, K.; Hu, C.; Xing, F.; Gao, M.; Liang, J.; Xiao, X.; Cai, J.; Tan, Y.; Hu, J.; Zhu, W.; et al. Deficiency of the IRE1alpha-Autophagy Axis Enhances the Antitumor Effects of the Oncolytic Virus M1. J. Virol. 2018, 92, e01331-17. [CrossRef]

40. Healy, S.J.; Gorman, A.M.; Mousavi-Shafaei, P.; Gupta, S.; Samali, A. Targeting the endoplasmic reticulum-stress response as an anticancer strategy. Eur. J. Pharmacol. 2009, 625, 234-246. [CrossRef]

41. Xu, H.; Liu, P.; Yan, Y.; Fang, K.; Liang, D.; Hou, X.; Zhang, X.; Wu, S.; Ma, J.; Wang, R.; et al. FKBP9 promotes the malignant behavior of glioblastoma cells and confers resistance to endoplasmic reticulum stress inducers. J. Exp. Clin. Cancer Res. 2020, 39, 44. [CrossRef] [PubMed]

42. Xi, Y.; Lindenmayer, L.; Kline, I.; von Einem, J.; Purdy, J.G. Human Cytomegalovirus Uses a Host Stress Response To Balance the Elongation of Saturated/Monounsaturated and Polyunsaturated Very-Long-Chain Fatty Acids. mBio 2021, 12, e00167-21. [CrossRef] [PubMed]

43. Honma, Y.; Miyagawa, K.; Hara, Y.; Hayashi, T.; Kusanaga, M.; Ogino, N.; Minami, S.; Oe, S.; Ikeda, M.; Hino, K.; et al. Correlation of hepatitis $\mathrm{C}$ virus-mediated endoplasmic reticulum stress with autophagic flux impairment and hepatocarcinogenesis. Med. Mol. Morphol. 2021, 54, 108-121. [CrossRef]

44. Ganesan, M.; Mathews, S.; Makarov, E.; Petrosyan, A.; Kharbanda, K.K.; Kidambi, S.; Poluektova, L.Y.; Casey, C.A.; Osna, N.A. Acetaldehyde suppresses HBV-MHC class I complex presentation on hepatocytes via induction of ER stress and Golgi fragmentation. Am. J. Physiol. Gastrointest. Liver Physiol. 2020, 319, G432-G442. [CrossRef] [PubMed]

45. Dimcheff, D.E.; Volkert, L.G.; Li, Y.; DeLucia, A.L.; Lynch, W.P. Gene expression profiling of microglia infected by a highly neurovirulent murine leukemia virus: Implications for neuropathogenesis. Retrovirology 2006, 3, 26. [CrossRef]

46. Dimcheff, D.E.; Faasse, M.A.; McAtee, F.J.; Portis, J.L. Endoplasmic reticulum (ER) stress induced by a neurovirulent mouse retrovirus is associated with prolonged BiP binding and retention of a viral protein in the ER. J. Biol. Chem. 2004, 279, 33782-33790. [CrossRef]

47. Shao, X.; Wang, X.; Guo, X.; Jiang, K.; Ye, T.; Chen, J.; Fang, J.; Gu, L.; Wang, S.; Zhang, G.; et al. STAT3 Contributes To Oncolytic Newcastle Disease Virus-Induced Immunogenic Cell Death in Melanoma Cells. Front. Oncol. 2019, 9, 436. [CrossRef]

48. Hamed, H.A.; Yacoub, A.; Park, M.A.; Eulitt, P.; Sarkar, D.; Dimitrie, I.P.; Chen, C.S.; Grant, S.; Curiel, D.T.; Fisher, P.B.; et al. OSU-03012 enhances Ad.7-induced GBM cell killing via ER stress and autophagy and by decreasing expression of mitochondrial protective proteins. Cancer Biol. Ther. 2010, 9, 526-536. [CrossRef]

49. Mahoney, D.J.; Lefebvre, C.; Allan, K.; Brun, J.; Sanaei, C.A.; Baird, S.; Pearce, N.; Gronberg, S.; Wilson, B.; Prakesh, M.; et al. Virus-tumor interactome screen reveals ER stress response can reprogram resistant cancers for oncolytic virus-triggered caspase-2 cell death. Cancer Cell 2011, 20, 443-456. [CrossRef] 
50. Senft, D.; Ronai, Z.A. UPR, autophagy, and mitochondria crosstalk underlies the ER stress response. Trends Biochem. Sci. 2015, 40, 141-148. [CrossRef]

51. Wang, Y.; Zhang, N.; Zhang, L.; Li, R.; Fu, W.; Ma, K.; Li, X.; Wang, L.; Wang, J.; Zhang, H.; et al. Autophagy Regulates Chromatin Ubiquitination in DNA Damage Response through Elimination of SQSTM1/p62. Mol. Cell 2016, 63, 34-48. [CrossRef] [PubMed]

52. Johnston, B.P.; Pringle, E.S.; McCormick, C. KSHV activates unfolded protein response sensors but suppresses downstream transcriptional responses to support lytic replication. PLoS Pathog. 2019, 15, e1008185. [CrossRef]

53. Shi, J.; Luo, H. Interplay between the cellular autophagy machinery and positive-stranded RNA viruses. Acta Biochim. Biophys. Sin. (Shanghai) 2012, 44, 375-384. [CrossRef]

54. Georgi, F.; Greber, U.F. The Adenovirus Death Protein-a small membrane protein controls cell lysis and disease. FEBS Lett. 2020, 594, 1861-1878. [CrossRef] [PubMed]

55. Zhang, B.; Yan, Y.; Jin, J.; Lin, H.; Li, Z.; Zhang, X.; Liu, J.; Xi, C.; Lieber, A.; Fan, X.; et al. Two types of functionally distinct fiber containing structural protein complexes are produced during infection of adenovirus serotype 5. PLoS ONE 2015, 10, e0117976. [CrossRef] [PubMed]

56. Sardo, L.; Iordanskiy, S.; Klase, Z.; Kashanchi, F. HIV-1 Nef blocks autophagy in human astrocytes. Cell Cycle 2015, 14, 3781-3782. [CrossRef]

57. Wu, X.; Dong, H.; Ye, X.; Zhong, L.; Cao, T.; Xu, Q.; Wang, J.; Zhang, Y.; Xu, J.; Wang, W.; et al. HIV-1 Tat increases BAG3 via NF-kappaB signaling to induce autophagy during HIV-associated neurocognitive disorder. Cell Cycle 2018, 17, 1614-1623. [CrossRef]

58. McLaughlin, M.; Pedersen, M.; Roulstone, V.; Bergerhoff, K.F.; Smith, H.G.; Whittock, H.; Kyula, J.N.; Dillon, M.T.; Pandha, H.S.; Vile, R.; et al. The PERK Inhibitor GSK2606414 Enhances Reovirus Infection in Head and Neck Squamous Cell Carcinoma via an ATF4-Dependent Mechanism. Mol. Ther. Oncolytics 2020, 16, 238-249. [CrossRef]

59. Prasad, V.; Suomalainen, M.; Pennauer, M.; Yakimovich, A.; Andriasyan, V.; Hemmi, S.; Greber, U.F. Chemical induction of unfolded protein response enhances cancer cell killing through lytic virus infection. J. Virol. 2014, 88, 13086-13098. [CrossRef] [PubMed]

60. Yoo, J.Y.; Hurwitz, B.S.; Bolyard, C.; Yu, J.G.; Zhang, J.; Selvendiran, K.; Rath, K.S.; He, S.; Bailey, Z.; Eaves, D.; et al. Bortezomibinduced unfolded protein response increases oncolytic HSV-1 replication resulting in synergistic antitumor effects. Clin. Cancer Res. 2014, 20, 3787-3798. [CrossRef]

61. Boozari, B.; Mundt, B.; Woller, N.; Struver, N.; Gurlevik, E.; Schache, P.; Kloos, A.; Knocke, S.; Manns, M.P.; Wirth, T.C.; et al. Antitumoural immunity by virus-mediated immunogenic apoptosis inhibits metastatic growth of hepatocellular carcinoma. Gut 2010, 59, 1416-1426. [CrossRef] [PubMed]

62. Dong, C.; Zhang, J.; Fang, S.; Liu, F. IGFBP5 increases cell invasion and inhibits cell proliferation by EMT and Akt signaling pathway in Glioblastoma multiforme cells. Cell Div. 2020, 15, 4. [CrossRef]

63. Rutkowska, A.; Stoczynska-Fidelus, E.; Janik, K.; Wlodarczyk, A.; Rieske, P. EGFR(vIII): An Oncogene with Ambiguous Role. J. Oncol. 2019, 2019, 1092587. [CrossRef]

64. Ulasov, I.; Fares, J.; Timashev, P.; Lesniak, M.S. Editing Cytoprotective Autophagy in Glioma: An Unfulfilled Potential for Therapy. Trends Mol. Med. 2020, 26, 252-262. [CrossRef]

65. Tanimoto, T.; Tazawa, H.; Ieda, T.; Nouso, H.; Tani, M.; Oyama, T.; Urata, Y.; Kagawa, S.; Noda, T.; Fujiwara, T. Elimination of MYCN-Amplified Neuroblastoma Cells by Telomerase-Targeted Oncolytic Virus via MYCN Suppression. Mol. Ther. Oncolytics 2020, 18, 14-23. [CrossRef]

66. Gonzalez-Morales, A.; Zabaleta, A.; Garcia-Moure, M.; Alonso, M.M.; Fernandez-Irigoyen, J.; Santamaria, E. Oncolytic adenovirus Delta-24-RGD induces a widespread glioma proteotype remodeling during autophagy. J. Proteom. 2019, 194, 168-178. [CrossRef]

67. Niu, Y.; Sun, Q.; Zhang, G.; Liu, X.; Shang, Y.; Xiao, Y.; Liu, S. Fowl adenovirus serotype 4-induced apoptosis, autophagy, and a severe inflammatory response in liver. Vet. Microbiol. 2018, 223, 34-41. [CrossRef]

68. Li, L.; You, L.S.; Mao, L.P.; Jin, S.H.; Chen, X.H.; Qian, W.B. Combing oncolytic adenovirus expressing Beclin-1 with chemotherapy agent doxorubicin synergistically enhances cytotoxicity in human CML cells in vitro. Acta Pharmacol. Sin. 2018, 39, 251-260 [CrossRef]

69. Zhang, J.; Lai, W.; Li, Q.; Yu, Y.; Jin, J.; Guo, W.; Zhou, X.; Liu, X.; Wang, Y. A novel oncolytic adenovirus targeting Wnt signaling effectively inhibits cancer-stem like cell growth via metastasis, apoptosis and autophagy in HCC models. Biochem. Biophys. Res. Commun. 2017, 491, 469-477. [CrossRef] [PubMed]

70. Hamed, H.A.; Yacoub, A.; Park, M.A.; Archer, K.; Das, S.K.; Sarkar, D.; Grant, S.; Fisher, P.B.; Dent, P. Histone deacetylase inhibitors interact with melanoma differentiation associated-7/interleukin-24 to kill primary human glioblastoma cells. Mol. Pharmacol. 2013, 84, 171-181. [CrossRef] [PubMed]

71. Yokoyama, T.; Iwado, E.; Kondo, Y.; Aoki, H.; Hayashi, Y.; Georgescu, M.M.; Sawaya, R.; Hess, K.R.; Mills, G.B.; Kawamura, H.; et al. Autophagy-inducing agents augment the antitumor effect of telerase-selve oncolytic adenovirus OBP-405 on glioblastoma cells. Gene. Ther. 2008, 15, 1233-1239. [CrossRef] [PubMed]

72. Kruyt, F.A.; Curiel, D.T. Toward a new generation of conditionally replicating adenoviruses: Pairing tumor selectivity with maximal oncolysis. Hum. Gene. Ther. 2002, 13, 485-495. [CrossRef] [PubMed]

73. Chen, P.H.; Ornelles, D.A.; Shenk, T. The adenovirus L3 23-kilodalton proteinase cleaves the amino-terminal head domain from cytokeratin 18 and disrupts the cytokeratin network of HeLa cells. J. Virol. 1993, 67, 3507-3514. [CrossRef] [PubMed] 
74. Tollefson, A.E.; Scaria, A.; Hermiston, T.W.; Ryerse, J.S.; Wold, L.J.; Wold, W.S. The adenovirus death protein (E3-11.6K) is required at very late stages of infection for efficient cell lysis and release of adenovirus from infected cells. J. Virol. 1996, 70, $2296-2306$. [CrossRef]

75. Ito, H.; Aoki, H.; Kuhnel, F.; Kondo, Y.; Kubicka, S.; Wirth, T.; Iwado, E.; Iwamaru, A.; Fujiwara, K.; Hess, K.R.; et al. Autophagic cell death of malignant glioma cells induced by a conditionally replicating adenovirus. J. Natl. Cancer Inst. 2006, 98, 625-636. [CrossRef] [PubMed]

76. Fujiwara, T.; Urata, Y.; Tanaka, N. Telomerase-specific oncolytic virotherapy for human cancer with the hTERT promoter. Curr. Cancer Drug Targets 2007, 7, 191-201. [CrossRef] [PubMed]

77. Putzer, B.M.; Stiewe, T.; Parssanedjad, K.; Rega, S.; Esche, H. E1A is sufficient by itself to induce apoptosis independent of p53 and other adenoviral gene products. Cell Death Differ. 2000, 7, 177-188. [CrossRef]

78. Colunga, A.G.; Laing, J.M.; Aurelian, L. The HSV-2 mutant DeltaPK induces melanoma oncolysis through nonredundant death programs and associated with autophagy and pyroptosis proteins. Gene. Ther. 2010, 17, 315-327. [CrossRef]

79. Perkins, D.; Pereira, E.F.; Aurelian, L. The herpes simplex virus type 2 R1 protein kinase (ICP10 PK) functions as a dominant regulator of apoptosis in hippocampal neurons involving activation of the ERK survival pathway and upregulation of the antiapoptotic protein Bag-1. J. Virol. 2003, 77, 1292-1305. [CrossRef] [PubMed]

80. Kanai, R.; Zaupa, C.; Sgubin, D.; Antoszczyk, S.J.; Martuza, R.L.; Wakimoto, H.; Rabkin, S.D. Effect of gamma34.5 deletions on oncolytic herpes simplex virus activity in brain tumors. J. Virol. 2012, 86, 4420-4431. [CrossRef] [PubMed]

81. Evans, A.S.; Lennemann, N.J.; Coyne, C.B. BPIFB3 Regulates Endoplasmic Reticulum Morphology To Facilitate Flavivirus Replication. J. Virol. 2020, 94, e00029-20. [CrossRef]

82. Freeman, A.I.; Zakay-Rones, Z.; Gomori, J.M.; Linetsky, E.; Rasooly, L.; Greenbaum, E.; Rozenman-Yair, S.; Panet, A.; Libson, E.; Irving, C.S.; et al. Phase I/II trial of intravenous NDV-HUJ oncolytic virus in recurrent glioblastoma multiforme. Mol. Ther. 2006, 13, 221-228. [CrossRef] [PubMed]

83. Botta, G.; Passaro, C.; Libertini, S.; Abagnale, A.; Barbato, S.; Maione, A.S.; Hallden, G.; Beguinot, F.; Formisano, P.; Portella, G. Inhibition of autophagy enhances the effects of E1A-defective oncolytic adenovirus d1922-947 against glioma cells in vitro and in vivo. Hum. Gene Ther. 2012, 23, 623-634. [CrossRef]

84. Bhutia, S.K.; Dash, R.; Das, S.K.; Azab, B.; Su, Z.Z.; Lee, S.G.; Grant, S.; Yacoub, A.; Dent, P.; Curiel, D.T.; et al. Mechanism of autophagy to apoptosis switch triggered in prostate cancer cells by antitumor cytokine melanoma differentiation-associated gene 7/interleukin-24. Cancer Res. 2010, 70, 3667-3676. [CrossRef] [PubMed]

85. Mauthe, M.; Langereis, M.; Jung, J.; Zhou, X.; Jones, A.; Omta, W.; Tooze, S.A.; Stork, B.; Paludan, S.R.; Ahola, T.; et al. An siRNA screen for ATG protein depletion reveals the extent of the unconventional functions of the autophagy proteome in virus replication. J. Cell Biol. 2016, 214, 619-635. [CrossRef]

86. Berghauser Pont, L.M.; Kleijn, A.; Kloezeman, J.J.; van den Bossche, W.; Kaufmann, J.K.; de Vrij, J.; Leenstra, S.; Dirven, C.M.; Lamfers, M.L. The HDAC Inhibitors Scriptaid and LBH589 Combined with the Oncolytic Virus Delta24-RGD Exert Enhanced Anti-Tumor Efficacy in Patient-Derived Glioblastoma Cells. PLoS ONE 2015, 10, e0127058. [CrossRef] [PubMed]

87. Ulasov, I.V.; Tyler, M.A.; Zhu, Z.B.; Han, Y.; He, T.C.; Lesniak, M.S. Oncolytic adenoviral vectors which employ the survivin promoter induce glioma oncolysis via a process of beclin-dependent autophagy. Int. J. Oncol. 2009, 34, 729-742. [PubMed]

88. Abraham, R.; Mudaliar, P.; Padmanabhan, A.; Sreekumar, E. Induction of cytopathogenicity in human glioblastoma cells by chikungunya virus. PLoS ONE 2013, 8, e75854. [CrossRef]

89. Rodriguez-Rocha, H.; Gomez-Gutierrez, J.G.; Garcia-Garcia, A.; Rao, X.M.; Chen, L.; McMasters, K.M.; Zhou, H.S. Adenoviruses induce autophagy to promote virus replication and oncolysis. Virology 2011, 416, 9-15. [CrossRef]

90. Piya, S.; White, E.J.; Klein, S.R.; Jiang, H.; McDonnell, T.J.; Gomez-Manzano, C.; Fueyo, J. The E1B19K oncoprotein complexes with Beclin 1 to regulate autophagy in adenovirus-infected cells. PLoS ONE 2011, 6, e29467. [CrossRef]

91. Wang, Y.; Wang, R.; Li, F.; Wang, Y.; Zhang, Z.; Wang, Q.; Ren, Z.; Jin, F.; Kitazato, K.; Wang, Y. Heat-shock protein 90alpha is involved in maintaining the stability of VP16 and VP16-mediated transactivation of alpha genes from herpes simplex virus-1. Mol. Med. 2018, 24, 65. [CrossRef]

92. Lai, J.K.F.; Sam, I.C.; Verlhac, P.; Baguet, J.; Eskelinen, E.L.; Faure, M.; Chan, Y.F. 2BC Non-Structural Protein of Enterovirus A71 Interacts with SNARE Proteins to Trigger Autolysosome Formation. Viruses 2017, 9, 169. [CrossRef] [PubMed]

93. Brown, M.C.; Dobrikov, M.I.; Gromeier, M. Mitogen-activated protein kinase-interacting kinase regulates mTOR/AKT signaling and controls the serine/arginine-rich protein kinase-responsive type 1 internal ribosome entry site-mediated translation and viral oncolysis. J. Virol. 2014, 88, 13149-13160. [CrossRef] [PubMed]

94. Li, B.; Zhou, C.; Yi, L.; Xu, L.; Xu, M. Effect and molecular mechanism of mTOR inhibitor rapamycin on temozolomide-induced autophagic death of U251 glioma cells. Oncol. Lett. 2018, 15, 2477-2484. [CrossRef]

95. Arcella, A.; Biagioni, F.; Antonietta Oliva, M.; Bucci, D.; Frati, A.; Esposito, V.; Cantore, G.; Giangaspero, F.; Fornai, F. Rapamycin inhibits the growth of glioblastoma. Brain Res. 2013, 1495, 37-51. [CrossRef] [PubMed]

96. Vilella-Bach, M.; Nuzzi, P.; Fang, Y.; Chen, J. The FKBP12-rapamycin-binding domain is required for FKBP12-rapamycinassociated protein kinase activity and G1 progression. J. Biol. Chem. 1999, 274, 4266-4272. [CrossRef]

97. Zemp, F.J.; Lun, X.; McKenzie, B.A.; Zhou, H.; Maxwell, L.; Sun, B.; Kelly, J.J.; Stechishin, O.; Luchman, A.; Weiss, S.; et al. Treating brain tumor-initiating cells using a combination of myxoma virus and rapamycin. Neuro Oncol. 2013, 15, 904-920. [CrossRef] [PubMed] 
98. Lun, X.; Alain, T.; Zemp, F.J.; Zhou, H.; Rahman, M.M.; Hamilton, M.G.; McFadden, G.; Bell, J.; Senger, D.L.; Forsyth, P.A. Myxoma virus virotherapy for glioma in immunocompetent animal models: Optimizing administration routes and synergy with rapamycin. Cancer Res. 2010, 70, 598-608. [CrossRef]

99. Lun, X.; Chan, J.; Zhou, H.; Sun, B.; Kelly, J.J.; Stechishin, O.O.; Bell, J.C.; Parato, K.; Hu, K.; Vaillant, D.; et al. Efficacy and safety/toxicity study of recombinant vaccinia virus JX-594 in two immunocompetent animal models of glioma. Mol. Ther. 2010, 18, 1927-1936. [CrossRef] [PubMed]

100. Lun, X.Q.; Jang, J.H.; Tang, N.; Deng, H.; Head, R.; Bell, J.C.; Stojdl, D.F.; Nutt, C.L.; Senger, D.L.; Forsyth, P.A.; et al. Efficacy of systemically administered oncolytic vaccinia virotherapy for malignant gliomas is enhanced by combination therapy with rapamycin or cyclophosphamide. Clin. Cancer Res. 2009, 15, 2777-2788. [CrossRef]

101. Alain, T.; Lun, X.; Martineau, Y.; Sean, P.; Pulendran, B.; Petroulakis, E.; Zemp, F.J.; Lemay, C.G.; Roy, D.; Bell, J.C.; et al. Vesicular stomatitis virus oncolysis is potentiated by impairing mTORC1-dependent type I IFN production. Proc. Natl. Acad. Sci. USA 2010, 107, 1576-1581. [CrossRef]

102. Cheema, T.A.; Kanai, R.; Kim, G.W.; Wakimoto, H.; Passer, B.; Rabkin, S.D.; Martuza, R.L. Enhanced antitumor efficacy of low-dose Etoposide with oncolytic herpes simplex virus in human glioblastoma stem cell xenografts. Clin. Cancer Res. 2011, 17, 7383-7393. [CrossRef]

103. Cerniglia, G.J.; Karar, J.; Tyagi, S.; Christofidou-Solomidou, M.; Rengan, R.; Koumenis, C.; Maity, A. Inhibition of autophagy as a strategy to augment radiosensitization by the dual phosphatidylinositol 3-kinase/mammalian target of rapamycin inhibitor NVP-BEZ235. Mol. Pharmacol. 2012, 82, 1230-1240. [CrossRef]

104. Geletneky, K.; Hartkopf, A.D.; Krempien, R.; Rommelaere, J.; Schlehofer, J.R. Improved killing of human high-grade glioma cells by combining ionizing radiation with oncolytic parvovirus H-1 infection. J. Biomed. Biotechnol. 2010, 2010, 350748. [CrossRef]

105. Burton, C.; Das, A.; McDonald, D.; Vandergrift, W.A., 3rd; Patel, S.J.; Cachia, D.; Bartee, E. Oncolytic myxoma virus synergizes with standard of care for treatment of glioblastoma multiforme. Oncolytic Virother. 2018, 7, 107-116. [CrossRef] [PubMed]

106. Jiang, B.; Lun, X.; Hao, X.; Wang, Y.; Yin, X.; Huang, D.; He, W.; Wang, Z. Temozolomide resistant human brain tumor stem cells are susceptible to recombinant vesicular stomatitis virus and double-deleted Vaccinia virus in vitro. Biomed. Pharmacother. 2017, 95, 1201-1208. [CrossRef] [PubMed]

107. Bai, Y.; Chen, Y.; Hong, X.; Liu, X.; Su, X.; Li, S.; Dong, X.; Zhao, G.; Li, Y. Newcastle disease virus enhances the growth-inhibiting and proapoptotic effects of temozolomide on glioblastoma cells in vitro and in vivo. Sci. Rep. 2018, 8, 11470. [CrossRef] [PubMed] 